\title{
Gender Factor-Impact on Employability: Special Reference to the Management Students in Kerala
}

\author{
S. Edmund Christopher ${ }^{1 *}$, K.M. Pradeep ${ }^{2}$ \\ ${ }^{1}$ Dean Of Academic Affairs, ECMIT, Dubai, UAE. \\ ${ }^{2}$ Research Scholar, Faculty Of Management Studies, Noorul Islam Centre For Higher Education, Tamil Nadu, India. \\ E-Mail:Kmpradeep_2000@Rediffmail.Com \\ *Corresponding Author E-Mail:Edmundchristo@Gmail.Com
}

\begin{abstract}
Kerala is the State having height in Human development Index in the Country. It has got the highest literacy rate and also number one in female literacy. In case of employment Kerala is one among the last states of the country. Kerala the advantage is the state was declared as a state with $100 \%$ literacy. The women literacy rate is also higher in the state, People are having good economic and cultural back ground. Good at education and other economic aspects of life. Among the 3,34 crores of the people (Census 2011) 1.6 crores are male and 1.74are female. If we take the percentage of literacy $96.11 \%$ men and $92.07 \%$ women are literate. The women in the state are strong enough to work in corporate culture. The problem generally faces in Kerala is there is not much of job opportunities in Kerala and hence employability. Women are equally a good work force in Kerala compared to men provided they should have opportunity to be given.
\end{abstract}

Keywords: Employment opportunities, education, skill development, literacy, employability, gender.

\section{Introduction}

Kerala is referred as Gods own country due to Its scenic beauty, highest literacy rate and equip distributed economy. When we study the employment scenario of the state the above name doesn't matches as the employability is very poor among the educated crowd of the state. It is a State registered with highest literacy rate in the country but the challenges are comparatively very high for the employers while recruiting from Kerala. The State is one of the topmost in the Human Development Index (HDI), this alone may not help in the Employment Market especially in Corporate Employment Market. We are trying to understand the common challenges faced by Employers in Kerala in terms of recruitment and what are all the possible corrective measures can be taken to address these issues. It is utmost important to understand the requirements of the employer and match it with the aspirations of the talent available .Gaining better understanding of the challenges will help us to improve the employability and thereby employment opportunities. The education system, especially management education of the state facing lots of challenges. This results in employment readiness or employability among the students. Kerala is being a state with high political awareness and activism; we are trying to find out how this affected the employment market of the state. Also the states register their highest share of revenue through NRI (NRK) income. Lots of people from the state pursuing their career abroad as they have strong roots there.( Especially in gulf countries) The state is rich with NRI money and employment is also upto an extend depending on gulf countries. We are trying to study the impact of the current management education system towards employability and trying to find out possible draw backs of the system through the survey.

\section{Challenges and Opportunities}

When discussion about the challenges the major challenges are the one we have discussed earlier like geographical constraints, high awareness on human rights and also political influence on the entire society. This leads to trade unionism and there by minimal manufacturing industries and hence minimal employment. This is a challenge for the state as a whole. The lack of industry and tradition of business as a state is also poor at the state. Gender difference in work place and performance also affected as the corporate culture itself is relatively new to the state. Recently due to the powerful growth of IT sector in the state Kerala also shows good response on wemen employment. 


\section{Statement of the problem}

The state SI having the highest literacy rate , high human value index and limited population enough education opportunities and health standards,. Still the state is poor in employing females and also not matured enough to have perfect corporate culture. we are trying to find out how gender difference impact the employability and employment scenario in the state.

\section{Scope of the study}

The concept of employability means the process of achieving the employment suitable to their skill and education and remain in the job successfully through out the career. Today the women are empowered for any initiative in the society. A state like Kerala it is important to know how the gender difference impacts the employability and hence productivity.

\section{Objectives of the study}

To find out how gender differs Theoretical Knowledge.

To find out how gender differs in practical Knowledge.

To find out how gender differs in communication skills.

To find out how gender differs in System skills.

To find out how gender differs in problem solving skills.

To find out how gender differs in inter personal skills.

To find out how gender differs if key roles assigned.

To find out weather curriculum suitable for both boys and girls.

\section{Research Method}

\section{Primary data}

Collected using questionnaire. The confidence level of the students is $95 \%$ whereas the confidence interval is $5 \%$ of the total population of 10000 students. Therefore, the sample size of the students is 370 . The confidence level of the HR managers is $95 \%$ whereas the confidence interval is $5 \%$ of the total population of 1200 HR managers. Therefore the sample size of the HR managers is 290 .

\section{Secondary data}

Collected from Government records, Previous related studies, Journals, news papers and from discussion with management teachers of different colleges.

\section{Gender factor}

In this Chi-square hypothesis, it is analysed that whether gender factor plays a significant role in corporate employability or not and found that there is no gender-based significant difference in institutes in Kerala.

H3: gender factor plays a significant role in corporate employability.

H0: gender factor does not play a significant role in corporate employability.

\section{Candidates have enough theoretical knowledge*Gender}

Table 1: Chi-Square Tests

\begin{tabular}{|l|c|c|}
\hline & Value & df \\
\hline Pearson Chi-Square & $0.079^{\mathrm{a}}$ & 4 \\
\hline Likelihood Ratio & 0.079 & 4 \\
\hline Linear-by-Linear Association & 0.038 & 1 \\
\hline N of Valid Cases & 660 & \\
\hline
\end{tabular}

a. 0 cells $(0.0 \%)$ have expected count less than 5 . The minimum expected count is 36.00 . From the above Table 1, it is clearly seen that the significance value is greater than 0.05 . Hence, it is found that there is no gender based significant difference in providing theoretical knowledge in institutes and the Null Hypothesis is accepted.

\section{Directional measures}

\begin{tabular}{|c|c|c|c|}
\hline & & & Value \\
\hline \multirow{5}{*}{$\begin{array}{l}\text { Nominal by } \\
\text { Nominal }\end{array}$} & \multirow[t]{3}{*}{ Lambda } & Symmetric & 0.004 \\
\hline & & $\begin{array}{l}\text { candidates have enough } \\
\text { theoretical knowledge } \\
\text { Dependent }\end{array}$ & 0.000 \\
\hline & & gender Dependent & 0.009 \\
\hline & \multirow[t]{2}{*}{$\begin{array}{l}\text { Goodman and } \\
\text { Kruskal tau }\end{array}$} & $\begin{array}{l}\text { candidates have enough } \\
\text { theoretical knowledge } \\
\text { Dependent }\end{array}$ & 0.000 \\
\hline & & gender Dependent & 0.000 \\
\hline \multicolumn{3}{|c|}{ Candidates } & \\
\hline
\end{tabular}

Table 2: Chi-Square Tests

\begin{tabular}{|l|c|c|}
\hline & Value & df \\
\hline Pearson Chi-Square & $5.745^{\mathrm{a}}$ & 4 \\
\hline Likelihood Ratio & 5.762 & 4 \\
\hline Linear-by-Linear Association & 2.263 & 1 \\
\hline N of Valid Cases & 660 & \\
\hline
\end{tabular}

a. 0 cells $(0.0 \%)$ have expected count less than 5 . The minimum expected count is 46.50 . From the above Table 2, it is clearly seen that the significance value is greater than 0.05 . Hence, it is found that there is no gender based significant difference in providing practical knowledge in institutes and the Null Hypothesis is accepted.

\section{Directional measures}

\begin{tabular}{|l|l|l|l|}
\hline \multicolumn{2}{|l|}{} & Value \\
\hline \multicolumn{2}{|l|}{} & Symmetric & 0.031 \\
\cline { 3 - 4 } $\begin{array}{l}\text { Nominal by } \\
\text { Nominal }\end{array}$ & Lambda & $\begin{array}{l}\text { candidates have enough } \\
\text { practical knowledge } \\
\text { Dependent }\end{array}$ & 0.000 \\
\cline { 3 - 4 } & gender Dependent & 0.076 \\
\hline
\end{tabular}




\begin{tabular}{|l|l|l|l|}
\hline & $\begin{array}{l}\text { candidates have enough } \\
\text { Goodman and } \\
\text { Kructical knowledge }\end{array}$ & 0.002 \\
Dependent & \begin{tabular}{l} 
prau \\
\cline { 3 - 4 }
\end{tabular} & gender Dependent & 0.009 \\
\hline
\end{tabular}

Candidates have enough communication knowledge*Gender

Table 3: Chi-Square Tests

\begin{tabular}{|l|c|c|}
\hline & Value & df \\
\hline Pearson Chi-Square & $0.209^{\mathrm{a}}$ & 4 \\
\hline Likelihood Ratio & 0.209 & 4 \\
\hline Linear-by-Linear Association & 0.003 & 1 \\
\hline N of Valid Cases & 660 & \\
\hline
\end{tabular}

a. 0 cells $(0.0 \%)$ have expected count less than 5 . The minimum

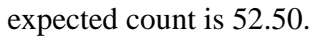

From the above table 3 , it is clearly seen that the significance value is greater than 0.05 .

Hence, it is found that there is no gender based significant difference in providing communication knowledge in institutes and the Null Hypothesis is accepted.

\section{Directional measures}

\begin{tabular}{|l|l|l|l|}
\hline \multicolumn{3}{|c|}{} & Value \\
\hline \multirow{3}{*}{\begin{tabular}{l}
\multirow{3}{*}{ Nominal by } \\
Nominal
\end{tabular}} & & Symmetric & 0.006 \\
\cline { 3 - 4 } & & $\begin{array}{l}\text { candidates have enough } \\
\text { communication knowledge Dependent }\end{array}$ & 0.000 \\
\cline { 3 - 4 } & \multirow{3}{*}{ Goodman and } & gender Dependent & 0.015 \\
\hline & Kruskal tau & communication knowledge Dependent & 0.000 \\
\cline { 3 - 4 } & gender Dependent & 0.000 \\
\hline
\end{tabular}

Candidates have enough presentation

knowledge*Gender

Table 4: Chi-Square Tests

\begin{tabular}{|l|c|c|}
\hline & Value & df \\
\hline Pearson Chi-Square & $0.013^{\mathrm{a}}$ & 4 \\
\hline Likelihood Ratio & 0.013 & 4 \\
\hline Linear-by-Linear Association & 0.001 & 1 \\
\hline N of Valid Cases & 660 & \\
\hline
\end{tabular}

0 cells $(0.0 \%)$ have expected count less than 5 . The minimum expected count is 40.00 . From the above Table 4 , it is clearly seen that the significance value is greater than 0.05 . Hence, it is found that there is no gender based significant difference in providing presentation knowledge in institutes and the Null Hypothesis is accepted.

\section{Directional measures}

\begin{tabular}{|c|c|c|c|}
\hline & & & Value \\
\hline & & Symmetric & 0.001 \\
\hline & Lambda & $\begin{array}{l}\text { candidates have enough } \\
\text { presentation knowledge } \\
\text { Dependent }\end{array}$ & 0.000 \\
\hline & & gender Dependent & 0.003 \\
\hline & $\begin{array}{l}\text { Goodman and } \\
\text { Kruskal tau }\end{array}$ & $\begin{array}{l}\text { candidates have enough } \\
\text { presentation knowledge } \\
\text { Dependent }\end{array}$ & 0.000 \\
\hline & & gender Dependent & 0.000 \\
\hline
\end{tabular}

Candidates have enough system knowledge * Gender

Table 5: Chi-Square Tests

\begin{tabular}{|l|c|c|}
\hline & Value & df \\
\hline Pearson Chi-Square & $0.362^{\mathrm{a}}$ & 4 \\
\hline Likelihood Ratio & 0.362 & 4 \\
\hline Linear-by-Linear Association & 0.110 & 1 \\
\hline N of Valid Cases & 660 & \\
\hline
\end{tabular}

0 cells $(0.0 \%)$ have expected count less than 5 . The minimum expected count is 46.50 .

From the above Table 5, it is clearly seen that the significance value is greater than 0.05 .

Hence, it is found that there is no gender based significant difference in providing system knowledge in institutes and the Null Hypothesis is accepted.

\section{Directional measures}

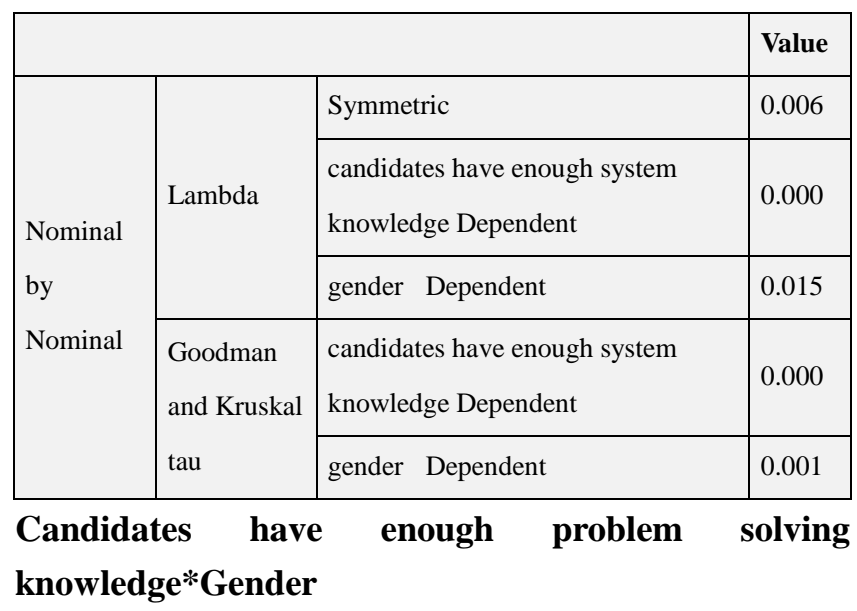

Table 6: Chi-Square Tests

\begin{tabular}{|l|c|c|}
\hline & Value & df \\
\hline Pearson Chi-Square & $0.858^{\mathrm{a}}$ & 4 \\
\hline Likelihood Ratio & 0.858 & 4 \\
\hline Linear-by-Linear Association & 0.104 & 1 \\
\hline N of Valid Cases & 660 & \\
\hline
\end{tabular}


0 cells $(0.0 \%)$ have expected count less than 5 . The minimum expected count is 53.00 .

From the above Table 6, it is clearly seen that the significance value is greater than 0.05 .

Hence, it is found that there is no gender based significant difference in providing problem-solving knowledge in institutes and the Null Hypothesis is accepted.

\section{Directional measures}

\begin{tabular}{|c|c|c|c|}
\hline & & & Value \\
\hline \multirow{5}{*}{$\begin{array}{l}\text { Nominal } \\
\text { by } \\
\text { Nominal }\end{array}$} & \multirow{3}{*}{ Lambda } & Symmetric & 0.011 \\
\hline & & $\begin{array}{l}\text { candidates have enough } \\
\text { problem solving knowledge } \\
\text { Dependent }\end{array}$ & 0.000 \\
\hline & & gender Dependent & 0.027 \\
\hline & \multirow[t]{2}{*}{$\begin{array}{l}\text { Goodman and } \\
\text { Kruskal tau }\end{array}$} & $\begin{array}{l}\text { candidates have enough } \\
\text { problem solving knowledge } \\
\text { Dependent }\end{array}$ & 0.000 \\
\hline & & gender Dependent & 0.001 \\
\hline
\end{tabular}

Candidates have good interpersonal skills * Gender

Table 7: Chi-Square Tests

\begin{tabular}{|l|c|c|}
\hline & Value & df \\
\hline Pearson Chi-Square & $0.546^{\mathrm{a}}$ & 4 \\
\hline Likelihood Ratio & 0.546 & 4 \\
\hline Linear-by-Linear Association & 0.205 & 1 \\
\hline N of Valid Cases & 660 & \\
\hline
\end{tabular}

0 cells $(0.0 \%)$ have expected count less than 5 . The minimum expected count is 53.00 .

From the above Table 7 , it is clearly seen that the significance value is greater than 0.05 .

Hence, it is found that there is no gender based significant difference in providing interpersonal skill in institutes and the Null Hypothesis is accepted.

\section{Directional measures}

\begin{tabular}{|l|l|l|l|}
\hline \multirow{2}{*}{} & \multirow{2}{|c|}{ Symmetric } & Value \\
\cline { 3 - 4 } \multirow{2}{*}{$\begin{array}{l}\text { Nominal by } \\
\text { Nominal }\end{array}$} & Lambda & $\begin{array}{l}\text { candidates have good } \\
\text { interpersonal skills Dependent }\end{array}$ & 0.000 \\
\cline { 3 - 5 } & \multirow{2}{*}{\begin{tabular}{l} 
Goodman and \\
\cline { 3 - 4 }
\end{tabular}} & $\begin{array}{l}\text { gender Dependent } \\
\text { Kruskal tau }\end{array}$ & 0.021 \\
\cline { 3 - 5 } & interpersonal skills Dependent & 0.000 \\
\cline { 3 - 5 } & gender Dependent & 0.001 \\
\hline
\end{tabular}

Candidates are having good attitude * Gender
Table 8: Chi-Square Tests

\begin{tabular}{|l|l|l|}
\hline & \multicolumn{1}{|c|}{ Value } & df \\
\hline Pearson Chi-Square & $.287^{\mathrm{a}}$ & 4 \\
\hline Likelihood Ratio & .287 & 4 \\
\hline Linear-by-Linear Association & .053 & 1 \\
\hline N of Valid Cases & 660 & \\
\hline
\end{tabular}

0 cells $(0.0 \%)$ have expected count less than 5 . The minimum expected count is 56.00 .

From the above Table 8 , it is clearly seen that the significance value is greater than 0.05 .

Hence, it is found that there is no gender based significant difference in having good attitude and the Null Hypothesis is accepted.

\section{Directional measures}

\begin{tabular}{|c|c|c|c|}
\hline & & & Value \\
\hline & & Symmetric & 0.006 \\
\hline & Lambda & $\begin{array}{l}\text { candidates are having good } \\
\text { attitude Dependent }\end{array}$ & 0.000 \\
\hline . & & gender Dependent & 0.015 \\
\hline & Goodman and & $\begin{array}{l}\text { candidates are having good } \\
\text { attitude Dependent }\end{array}$ & 0.000 \\
\hline & & gender Dependent & 0.000 \\
\hline
\end{tabular}

\section{Candidates are having career dreams * Gender}

Table 9: Chi-Square Tests

\begin{tabular}{|l|l|l|}
\hline & \multicolumn{1}{|c|}{ Value } & df \\
\hline Pearson Chi-Square & $.372^{\mathrm{a}}$ & 4 \\
\hline Likelihood Ratio & .372 & 4 \\
\hline Linear-by-Linear Association & .042 & 1 \\
\hline N of Valid Cases & 660 & \\
\hline
\end{tabular}

0 cells $(0.0 \%)$ have expected count less than 5 . The minimum expected count is 43.00 .

From the above Table 9, it is clearly seen that the significance value is greater than 0.05 .

Hence, it is found that there is no gender based significant difference in having career dreams and the Null Hypothesis is accepted.

\section{Directional measures}

\begin{tabular}{|c|c|c|c|}
\hline & & & Value \\
\hline \multirow{5}{*}{$\begin{array}{l}\text { Nominal by } \\
\text { Nominal }\end{array}$} & \multirow{3}{*}{ Lambda } & Symmetric & 0.006 \\
\hline & & $\begin{array}{l}\text { candidates are having career } \\
\text { dreams Dependent }\end{array}$ & 0.000 \\
\hline & & gender Dependent & 0.015 \\
\hline & \multirow{2}{*}{$\begin{array}{l}\text { Goodman and } \\
\text { Kruskal tau }\end{array}$} & $\begin{array}{l}\text { candidates are having career } \\
\text { dreams Dependent }\end{array}$ & 0.000 \\
\hline & & gender Dependent & 0.001 \\
\hline
\end{tabular}




\section{Colleges are providing good infrastructure * gender}

Table 10: Chi-Square Tests

\begin{tabular}{|l|l|l|}
\hline & \multicolumn{1}{|c|}{ Value } & \multicolumn{1}{c|}{ df } \\
\hline Pearson Chi-Square & $2.630^{\mathrm{a}}$ & 4 \\
\hline Likelihood Ratio & 2.634 & 4 \\
\hline Linear-by-Linear Association & .093 & 1 \\
\hline N of Valid Cases & 660 & \\
\hline
\end{tabular}

0 cells $(0.0 \%)$ have expected count less than 5 . The minimum expected count is 33.00 .

From the above Table 10, it is clearly seen that the significance value is greater than 0.05 .

Hence, it is found that there is no gender based significant difference in providing good infrastructure in institutes and the Null Hypothesis is accepted.

\section{Directional measures}

\begin{tabular}{|c|c|c|c|}
\hline & & & Value \\
\hline \multirow{5}{*}{$\begin{array}{l}\text { Nominal by } \\
\text { Nominal }\end{array}$} & \multirow{3}{*}{ Lambda } & Symmetric & 0.021 \\
\hline & & $\begin{array}{l}\text { colleges are providing good } \\
\text { infrastructure Dependent }\end{array}$ & 0.000 \\
\hline & & gender Dependent & 0.052 \\
\hline & \multirow{2}{*}{$\begin{array}{l}\text { Goodman and } \\
\text { Kruskal tau }\end{array}$} & $\begin{array}{l}\text { colleges are providing good } \\
\text { infrastructure Dependent }\end{array}$ & 0.001 \\
\hline & & gender Dependent & 0.004 \\
\hline
\end{tabular}

College faculties have enough industrial experience * Gender

Table 11: Chi-Square Tests

\begin{tabular}{|l|l|l|}
\hline & \multicolumn{1}{|c|}{ Value } & df \\
\hline Pearson Chi-Square & $2.272^{\mathrm{a}}$ & 4 \\
\hline Likelihood Ratio & 2.274 & 4 \\
\hline Linear-by-Linear Association & .357 & 1 \\
\hline N of Valid Cases & 660 & \\
\hline
\end{tabular}

0 cells $(0.0 \%)$ have expected count less than 5 . The minimum expected count is 57.00 .

From the above Table 11, it is clearly seen that the significance value is greater than 0.05 .

Hence, it is found that there is no gender based significant difference in being trained by college faculties as they have enough industrial experience and the Null Hypothesis is accepted.

\section{Directional measures}

\begin{tabular}{|l|l|l|l|}
\hline \multicolumn{2}{|l|}{} & Symmetric & Value \\
\hline \multirow{2}{*}{$\begin{array}{l}\text { Nominal by } \\
\text { Nominal }\end{array}$} & Lambda & $\begin{array}{l}\text { college faculties have enough } \\
\text { industrial experience Dependent }\end{array}$ & 0.000 \\
\cline { 3 - 4 } & gender Dependent & 0.055 \\
\hline
\end{tabular}

\begin{tabular}{|c|c|c|}
\hline $\begin{array}{l}\text { Goodman } \\
\text { and }\end{array}$ & $\begin{array}{l}\text { college faculties have enough } \\
\text { industrial experience Dependent }\end{array}$ & 0.001 \\
\hline $\begin{array}{l}\text { Kruskal } \\
\text { tau }\end{array}$ & gender Dependent & 0.003 \\
\hline
\end{tabular}

Colleges play a key role in employability * Gender

Table 12: Chi-Square Tests

\begin{tabular}{|l|c|c|}
\hline & Value & df \\
\hline Pearson Chi-Square & $.858^{\mathrm{a}}$ & 4 \\
\hline Likelihood Ratio & .858 & 4 \\
\hline Linear-by-Linear Association & .104 & 1 \\
\hline N of Valid Cases & 660 & \\
\hline
\end{tabular}

0 cells $(0.0 \%)$ have expected count less than 5 . The minimum expected count is 53.00 .

From the above Table 12, it is clearly seen that the significance value is greater than 0.05 .

Hence, it is found that there is no gender based significant difference in the key role of college in employability and the Null Hypothesis is accepted.

\section{Directional measures}

\begin{tabular}{|c|c|c|c|}
\hline & & & Value \\
\hline \multirow{5}{*}{$\begin{array}{l}\text { Nominal by } \\
\text { Nominal }\end{array}$} & \multirow{3}{*}{ Lambda } & Symmetric & 0.011 \\
\hline & & $\begin{array}{l}\text { colleges play a key role in } \\
\text { employability Dependent }\end{array}$ & 0.000 \\
\hline & & gender Dependent & 0.027 \\
\hline & \multirow{2}{*}{$\begin{array}{l}\text { Goodman and } \\
\text { Kruskal tau }\end{array}$} & $\begin{array}{l}\text { colleges play a key role in } \\
\text { employability Dependent }\end{array}$ & 0.000 \\
\hline & & gender Dependent & 0.001 \\
\hline
\end{tabular}

College curriculums meet our requirement * Gender

Table 13: Chi-Square Tests

\begin{tabular}{|l|l|l|}
\hline & \multicolumn{1}{|c|}{ Value } & \multicolumn{1}{c|}{ df } \\
\hline Pearson Chi-Square & $.437^{\mathrm{a}}$ & 4 \\
\hline Likelihood Ratio & .437 & 4 \\
\hline Linear-by-Linear Association & .001 & 1 \\
\hline N of Valid Cases & 660 & \\
\hline
\end{tabular}

0 cells $(0.0 \%)$ have expected count less than 5 . The minimum expected count is 56.00 .

From the above Table 13, it is clearly seen that the significance value is greater than 0.05 . Hence, it is found that there is no gender based significant difference in college curriculum and the Null Hypothesis is accepted.

\section{Directional measures}




\begin{tabular}{|l|l|l|c|}
\hline \multicolumn{2}{|l|}{} & Value \\
\hline \multirow{2}{*}{} & \multirow{2}{*}{$\begin{array}{l}\text { Symmetric } \\
\text { Nominal } \\
\text { by }\end{array}$} & $\begin{array}{l}\text { college curriculums meet } \\
\text { our requirement } \\
\text { Nominal } \\
\text { Dependent }\end{array}$ & 0.010 \\
\cline { 3 - 4 } & $\begin{array}{l}\text { Goodman } \\
\text { and }\end{array}$ & $\begin{array}{l}\text { gender Dependent } \\
\text { our college curriculums meet } \\
\text { Kruskal tau }\end{array}$ & 0.024 \\
\cline { 3 - 4 } & $\begin{array}{l}\text { Dependent } \\
\text { gender Dependent }\end{array}$ & 0.000 \\
\hline
\end{tabular}

\section{Conclusion}

In this Chi-square hypothesis, it is analysed that whether gender factor plays a significant role in corporate employability or not. Accordingly, it is found that there is no gender-based significant difference in institutes in Kerala because:

- Both male and female candidates have equal exposure to have enough theoretical knowledge.

- Both male and female candidates have equal exposure to have enough practical knowledge.

- Both male and female candidates have equal exposure to have enough communication knowledge.

- Both male and female candidates have equal exposure to have enough presentation knowledge.

- Both male and female candidates have equal exposure to have enough system knowledge.

- Both male and female candidates have equal exposure to have enough problems solving knowledge.

- Both male and female candidates have equal exposure to have good interpersonal skills.

- $\quad$ Both male and female candidates have equal exposure in having good attitude.

- Both male and female candidates have equal exposure in having career dreams.

- Both male and female candidates have equal exposure in getting good infrastructure.

- Faculties have enough industrial experience to teach both male and female candidates.

- Colleges play a key role in employability for both male and female candidates.

- College curriculums meet the requirement to teach both male and female candidates.

\section{References}

[1] Vikhe GV \& Preeti A, "Industry-Institute Employbility Skill Gap Analysis", International Journal of Research and Development A Management Review (IJRDMR), Vol.3, No.4, (2014), pp.16-19.

[2] Kumar NA \& George KK, Kerala's Education System: From Inclusion to Exclusion? Economic and Political Weekly, (2009), pp.55-61.

[3] Krishnan Sandeep K \& Rakesh B, "Corporate Social Responsibility as a determinant of market success: An exploratory analysis with special reference to MNCs in emerging markets", International Conference on NASMEI, IIM K, (2004).
[4] Gurusamy S \& Vengatesan C, "Green Banking - A Conceptual framework", Kaveripakkam College Journal of Management Research, Vol.4, No.12, (2014), pp.39-46.

[5] Kumar DS, Parwez A \& Parwez F, "Service Quality Measurement and Its Evaluation of Leading Private Banks of India in Delhi and NCR Region", An Analytical Study International Journal of Contemporary Business Studies, Vol.4, No.1, (2013).

[6] Neetu S, Sarika K \& Gopal R, “A Study on Consumer's awareness on Green Banking Initiatives in Selected Public and Private Sector Banks with Reference to Mumbai", IOSR Journal of Economics and Finance, (2014), pp.28-35.

[7] Edmund CS, "A Study on Buying Behaviour of Customers Towards Branded and Non-Branded Gold Jewellery with Reference to Kanyakumari District", International Journal of Management (IJM), Vol.5, No.10, (2014), pp.105-114.

[8] Edmund CS, "Re launching the Retailing in Small Towns: New Growth Frontiers Open Up in Rural India", International Journal of Marketing, Financial Services \& Management Research, Vol.3, No.7, (2014), pp.57-66.

[9] Edmund CS, "Reengineering the Process of Performance Evaluation towards the Employee's Development Need of the Time in IT Industry", Journal of Chemical and Pharmaceutical Sciences, (2016), pp.1823-1826.

[10] Edmund CS, "A Whiff of IT Industry Work Stress and Accelerating the Productivity: with Special Reference to Indian IT Industry", Zenith International Journal of Business Economics and Management Research, (2014).

[11] Edmund CS, Drain the Women Entrepreneurial Effort to Manage Global Crisis is The Need of an Hour A Focus Based on Indian Context”, GE-International Journal of Management Research (GE-IJMR), (2016). pp.87-97.

[12] Edmund Christopher. S, (2015), "An Analytical Study on Service Quality of Air India with Special Reference to Southern Region", International Journal of Applied Engineering Research, Research India Publications, ISSN 0973-4562, Vol.10, No.45, pp. 32021-32024.

[13] Edmund CS, "Employee Training and Development Practices in Air India - A Descriptive Glance with Reference to Chennai", International Journal of Applied Engineering Research, Research India Publications, Vol.10, No.45, (2015), pp.32005-32008.

[14] Edmund CS, "Performance of Air India with Special Reference to Passenger Fluctuations A Focus", Indian Stream Research Journal, Impact Factor. 2.1506 (UIF), Vol.4, No.10, (2014), pp.01-06.

[15] Dhanya JS \& Kinslin D, “A Study on Impact of Work Life Balance on Retention of Women Teachers in Management Colleges in Kerala", International Journal of Applied Business and Economic Research Vol.15, No.4, (2017).

[16] Dhanya JS \& Kinslin D, “A Study on Work Life Balance of Women Employees at ULCCS Ltd., Kozhikode", International Journal of Applied Business and Economic Research, Vol.15 No.4, (2017).

[17] Dhanya JS \& Kinslin D, "Clair Model for Better Work Life Balance and Empowerment of Women Faculty in Professional Colleges of Kerala", International Journal of Applied Business and Economic Research Vol.15 No.4, (2017).

[18] Cris K \& Kinslin D, "A Study on the Factors for Intermediary Dependence Among Decorative Paint Customers Exploring the Impact Significance", International Journal of Applied Business and Economic Research, Vol.15, No 6, (2017).

[19] Cris K \& Kinslin D, "A Study Among Decorative Paint Customers on Factors Influencing Preference of Decorative Paint Brands", 
International Journal of Applied Business and Economic Research, Vol.15, No.6, (2017).

[20] Cris K \& Kinslin D, "Problems and Challenges of Decorative Paint Customers in Paint Preference: A Study among Decorative Paint Customers of Kerala", International Journal of Applied Business and Economic Research, Vo.15, No.6, (2017).

[21] Cris K \& Kinslin D, "A study Explaining Branding Brand Experience among Decorative Paint Customers", International Journal of Applied Business and Economic Research, Vol.15, No.6, (2017).

[22] Arun P \& Kinslin D, “A Study on Entrepreneurial Leadership Skills and Human Resource Management in Small and medium Tourism Enterprises", International Journal of Applied Business and Economic Research, Vol.15, No.6, (2017).

[23] Shaji Y \& Kinslin, D, "Employee Retention Practices for Leaders A Study in Information Technology Organization", International Journal of Applied Engineering Research, Vol. No.10, (2015). 